\title{
Pertanggungjawaban Rumah Sakit terhadap Dokter yang Melakukan Malpraktik
}

\author{
Reza Havrian \\ Fakultas Hukum Universitas Indonesia \\ Jl. Timbangan No. 3, Kledung Kradenan RT 02/IV, Banyuurip, Purworejo, Jawa Tengah \\ Correspondence email: reza.havrian@ui.ac.id
}

\begin{abstract}
Abstrak. Rumah Sakit adalahinstitusi pelayanan kesehatan yangmenyelenggarakan pelayanan kesehatan perorangan secara paripurna yang menyediakan pelayanan rawat inap,rawat jalan,dan gawat darurat. Di Indonesia, praktik perumahsakitan diatur dalam Undang-undang No. 44 Tahun 2009 Tentang Rumah Sakit. Undang-undang tersebut, selain menjadi pedoman dasar hukum perumahsakitan, juga dibuat untuk lebih memberikan kepastian hukum dalam penyelenggaraan pelayanan kesehatan, maupun memberikan perlindungan bagi masyarakat dan perlindungan bagi sumber daya manusia di rumah sakit. Saat ini, rumah sakit dapat dimintakan pertanggungjawaban karena kondisi rumah sakit sudah tidak lagi institusi yang hanya mengedepankan asas untuk menolong orang saja. Rumah sakit perlahan berubah fungsi menjadi korporasiprovit oriented. Hal demikian terjadi karena semakin berkembangnya ilmu pengetahuan dan teknologi yang dinilai mahal sehingga para dokter dan pihak rumah sakit juga membutuhkan tambahan biaya untuk kelangsungan hidup. Adanya ketentuan rumah sakit bertanggung jawab atas kerugian seseorang sebagai akibat tindakan tenaga kesehatan, hal ini sebagai permintaan agar rumah sakit bertanggungjawab atas tindakan yang dilakukan oleh petugas profesi bawahannya baik sebagai status tetap maupun tidak tetap.Dokter sebagai salah satu pihak dalam perjanjian oleh rumah sakit memang memiliki prestasi untukmengupayakan penyembuhan pasien melalui pencarian terapi yang paling tepat danbukan pada menjanjikan kesembuhan dari pasien. Oleh karena itu, dokter memiliki tanggungjawab atas tindakan yang dilakukannya hanya sebatas upaya yang terbaik menurut ilmu pengetahuan dan pengalaman yang dimilikinya. Pertanggungjawaban rumah sakit terhadap dokter yang melakukan malpraktek memang tidak mutlak dan memiliki banyak celah. Berbeda halnya dengan ganti rugi pada hukum perdata, pertanggungjawaban pidana tetap dapat dituntutkan menggunakan doktrin-doktrin tentang pertanggungjawaban korporasi.
\end{abstract}

Kata Kunci: Pertanggungjawaban; Pertanggungjawaban Pidana; Rumah Sakit; Hukum Perumahsakitan; Dokter; Malpraktik

\begin{abstract}
Hospital is a health care institution that organizes individual health services in a plenary that provides inpatient, outpatient, and emergency services. In Indonesia, the practice of hospitals is governed by the law No. 44 year 2009 about hospitals. The law, in addition to being a basic guideline for legal and administrative, is also made to provide legal certainty in the maintenance of health services, as well as provide protection for the Community and protection of resources People in hospitals. Currently, hospitals can be held accountable because the condition of the hospital is no longer an institution that only focuses on the principle to help people only. The hospital slowly changed its function into a profit-oriented corporation. This is because the growing of science and technology are valued so much that doctors and hospitals also need additional costs for survival. The provisions of the hospital are responsible for the loss of a person as a result of the action of health workers, this is a request for the hospital to be responsible for te actions taken by the officers of his subordinates either as the status Fixed or not fixed. Doctors as a party to the agreement by the hospital do have the achievement to seek the healing of the patient through the search for the most appropriate therapy and not on promising healing from the patient. Therefore, doctors have a responsibility for the actions that do not only take the best effort according to the knowledge and experience he possesses. The hospital's accountability to doctors who do malpractice is not absolute and has many gaps. Unlike the damages to civil law, criminal liability can still be made by using the doctrine of corporate accountability.
\end{abstract}

Keywords: Liability; Criminal Liability; Hospitals; Hospital Law; Doctors; Malpractice

\section{PENDAHULUAN}

Rumah sakit adalah rumah tempat merawat orang sakit, menyediakan dan memberikan pelayanan kesehatan yang meliputi berbagai masalah kesehatan. ${ }^{1}$ Menurut WHO, Rumah Sakit adalah suatu badan usaha yang menyediakan pemondokan yang memberikan jasa pelayanan medik jangka pendek dan jangka panjang yang terdiri atas tindakan observasi, diagnostik, terpeutik dan rehabilitatif untuk orang-orang yang menderita sakit, terluka, mereka yang mau melahirkan dan menyediakan pelayanan berobat jalan ${ }^{2}$

Dasar hukum pengaturan Rumah Sakit diatur dalam UU No. 44 Tahun 2009 tentang Rumah Sakit, dalam Pasal 1 ayat (1) disebutkan bahwa 'rumah sakit adalah institusi pelayanan kesehatan yang menyelenggarakan pelayanan

\footnotetext{
${ }^{1}$ Depdikbud. Kamus Besar Bahasa Indonesia, edisi kedua, (Jakarta: Balai Pustaka, 1995), hlm. 851.

${ }^{2}$ Noor. M. Aziz, Laporan Penelitian Hukum Tentang Hubungan Tenaga Medik, Rumah Sakit dan Pasien, (Jakarta: Badan Pembinaan Hukum Nasional, Kementerian Hukum dan HAM RI, 2010), hlm. 44.
} 
kesehatan perorangan secara paripurna yang menyediakan pelayanan rawat inap, rawat jalan dan gawat darurat." 3 Adapun yang menjadi asas dan tujuan dari suatu rumah sakit diatur dalam Pasal 2 dan Pasal 3 bahwa: "rumah sakit diselenggarakan berasaskan Pancasila dan didasarkan kepada nilai kemanusiaan, etika dan profesionalisme, manfaat keadilan, persamaan hak dan anti diskriminasi, pemerataan, perlindungan dan keselamatan pasien, serta mempunyai fungsi sosial" 4

Pada mulanya Rumah sakit sebagai lembaga pelayanan kesehatan didirikan dengan latar belakang pelaksanaan tugas keagamaan atau pelaksanaan ibadah. Rumah sakit dalam konteks ini melaksanakan tugas semata-mata untuk tujuan sosial kemanusiaan sesuai dengan perintah agama. Pelayanan rumah sakit pada waktu itu terutama difokuskan pada pengobatan masyarakat yang kurang mampu. Soerjono Soekanto menjelaskan "rumah sakit sebagai lembaga derma pada saat itu hanya menyediakan ruangan, makanan maupun perawatan secara terbatas yang juga dilakukan oleh sukarelawan". ${ }^{5}$ Sehingga pada masa itu Rumah Sakit tidak dapat dituntut jika melakukan kesalahan, karena mereka sifatnya hanya membantu untuk menyembuhkan para orang-orang sakit yang tidak memiliki biaya.

Pada masa permulaan adanya rumah sakit di Amerika Serikat, Rumah Sakit merupakan suatu lembaga yang terlindungi oleh doktrin Charitable Immunity, ${ }^{6}$ artinya rumah sakit adalah lembaga merupakan lembaga karitas yang kental akan fungsi sosial. Akibatnya rumah sakit tidak dapat digugat, karena fungsi rumah sakit yang hanya berfungsi sosial untuk menolong masyarakat. Menurut Maeijer, Rumah Sakit sebagaimana dikutip oleh Soekanto: ${ }^{7}$

"Het ziekenhuis is een onderneming met een eigen karakter: het is gericht op medisch onderzoek en medische behandeling van opgenomen patienten. Het ziekenhuis is geen onderneming in de zin van een bedrijf dat is gericht op het maken van winst of enig vermogen srechtelijt voordeel."

"Rumah Sakit merupakan badan usaha yang mempunyai ciri tersendiri; usahanya tertuju pada pemeriksaan medis dan perawatan medis pasien yang masuk Rumah Sakit. Rumah Sakit bukan merupakan badan usaha dalam arti perusahaan yang bertujuan mencari untung atau keuntungan di bidang harta kekayaan."

Rumah Sakit sebagai badan usaha merupakan organ yang mempunyai kemandirian untuk melakukan perbuatan hukum (rechtshandeling). Rumah Sakit bukan manusia dalam arti "persoon" yang dapat berbuat dalam lalu lintas hukum masyarakat sebagai manusia (natuurijk persoon), namun ia (Rumah Sakit) diberi kedudukan menurut hukum sebagai persoon dan karenanya Rumah Sakit merupakan "rechtpersoon" dan oleh karena itu Rumah Sakit dibebani dengan hak dan kewajiban menurut hukum atas tindakan yang dilakukannya. ${ }^{8}$ Pemberian status sebagai "person" kepada Rumah Sakit oleh hukum sehingga ia berfungsi sebagai hukum (rechtpersoon) ini biasanya oleh Rumah Sakit swasta dituangkan dalam akta pendirian yayasan. ${ }^{9}$ Hak dan kewajiban rumah sakit dilakukan oleh organ Rumah Sakit yakni tenaga kesehatan yang terorganisir. Rumah sakit dalam sebuah badan hukum menyediakan layanan kesehatan berupa pelbagai sarana medis dan non medis yang permanen, menyelenggarakan pelayanan medis dan keperawatan secara berkesinambungan, termasuk pelayanan diagnosis dan pengobatan pasien.

Rumah Sakit dapat didasarkan pada hubungan Rumah Sakit dengan tenaga kesehatan yang bekerja, dan dihubungkan dengan pasien yang dirawat (baik di dalam maupun di luar Rumah Sakit). Hubungan yang harmonis antara dokter dan pasien hanya akan terwujud, jika dokter dan pasien sama-sama memahami dan menghayati hukum. Undang-Undang Nomor 44 Tahun 2009 tentang Rumah Sakit mengatur segala hal yang berhubungan dengan rumah sakit, termasuk sumber daya manusianya. Dalam Pasal 46 disebutkan tentang tanggungjawab hukum rumah sakit, yaitu "Rumah Sakit bertanggungjawab secara hukum terhadap semua kerugian yang ditimbulkan atas kelalaian yang dilakukan oleh tenaga kesehatan di Rumah Sakit". Pasal ini dirasakan kurang adil karena terlalu memihak tenaga kesehatan, termasuk dokter, yang sudah jelas bersalah karena lalai. Pasal ini juga dapat mengurangi rasa tanggungjawab dokter dalam penanganan pasien, karena tanggungjawab hukum atas kesalahannya sudah diambil alih oleh rumah sakit. Rumah sakit bukan merupakan individu yang dapat dihukum, sehingga yang terkena imbas kelalaian tersebut adalah pemilik dan manajemen rumah sakit. Ketidakadilan ini dapat digolongkan sebagai pelanggaran hak asasi manusia terhadap pemilik dan manajemen rumah sakit. Profesi dokter adalah suatu profesi dengan otonomi tinggi terutama pada dokter spesialis. Pemilik dan pengelola rumah sakit pada umumnya mempunyai pengetahuan yang terbatas tentang bidang kedokteran, khususnya yang spesialistik, sehingga sangat tidak adil bila pemilik atau

\footnotetext{
${ }^{3}$ Indonesia, Undang-undang Tentang Rumah Sakit, UU No. 44 Tahun 2009.

4 Ibid.

${ }^{5}$ Soerjono Soekanto, Aspek Hukum Kesehatan: Suatu Kumpulan Karangan,Cetakan I, (Jakarta: IND-HILL-Co, 1989), hlm.
}

100.

\footnotetext{
${ }^{6}$ Soerjono soekanto dan Herkutanto, Pengantar Hukum Kesehatan, (Bandung: Remadja Karya, 1987). hlm. 126

${ }^{7}$ Ibid, hlm. 129-130.

${ }^{8}$ Cahyono, Op. Cit., hlm. 50.

${ }^{9}$ Hermin Hadiati Koeswadji,Hukum Kedokteran, (Bandung: PT. Citra Aditya Bakti, 1998), hlm. 107.
} 
pengelola rumah sakit tersebut diharuskan untuk bertanggungjawab atas semua kerugian yang ditimbulkan oleh kelalaian dokter.

Pada praktik perumahsakitan, rumah sakit dapat diminta pertanggungjawaban karena kondisi sekarang ini rumah sakit sudah tidak lagi institusi yang hanya mengedepankan asas untuk menolong orang saja. Rumah sakit perlahan berubah fungsi menjadi provit oriented. Hal demikian terjadi karena semakin berkembangnya ilmu pengetahuan dan teknologi yang dinilai mahal sehingga para dokter dan pihak rumah sakit juga membutuhkan tambahan biaya untuk kelangsungan hidup.

Di banyak tempat di Indonesia, mutu pelayanan kesehatan rumah-sakit masih rendah. Keadaan demikian tidaklah dapat dibiarkan berlarut-larut, tetapi haruslah dicarikan jalan keluar untuk meningkatkannya, kalau perlu dengan mengadakan standarisasi. Pelayanan kesehatan rumah sakit di Indonesia dewasa ini, terutama di kota-kota besar menunjukkan perbedaan sosial yang cukup tajam. Bagi mereka yang mampu tersedia rumah-rumah sakit atau ruang-ruang khusus yang memberikan pelayanan khusus dengan tarif yang tidak terjangkau oleh sebagian besar masyarakat. Mutu pelayanan yang eksklusif dan terbaik menjadi hak bagi mereka. Sebaliknya bagi mereka yang kurang mampu mendapat pelayanan yang kurang memadai bahkan sering tidak manusiawi, kurang layak sehingga menimbulkan penderitaan yang lebih besar, disinilah bisa muncul peluang terjadinya kasus malpraktek medik.

Di Indonesia, sudah banyak kasus yang terjadi dalam bidang kedokteran, baik itu dibawa ke pengadilan maupun tidak. Diantara sekian banyak kasus yang ada, kasus-kasus yang tidak dibawa ke pengadilan tidaklah dapat diketahui banyaknya disebabkan kasus-kasus dibidang kedokteran ini sulit diketahui, disamping itu pihak pasien sebagai korban dalam hal ini belum menyadari bahwa kasus yang dideritanya adalah merupakan suatu kasus yang diakibatkan kesalahan diagnosa dan terapi pengobatan dari seorang dokter yang sebenarnya dapat dituntut ke pengadilan.

Sujudi dalam Djaelani saat Seminar dan Lokakarya Nasional Rumah Sakit Proaktif dalam Era Globalisasimengingatkan bahwa kinerja Pelayanan Rumah Sakit baik Pemerintah maupun Swasta dalam Liberalisasi Jasa Kesehatan di daerah perkotaan cenderung berorientasi pada mekanisme pasar. ${ }^{10}$ Djaelaniselanjutnya berpandangan: "Rumah sakit paradigmanya sudah bergeser dari fungsi sarana pelayanan (fungsiservice) ke fungsi penerima uang (fungsi budgetair), bahkan secara ekonomi Rumah Sakit merupakan pasar karena merupakan suatu permintaan (demand) danpenawaran (supply), bertemu untuk menukarkan barang dan jasa (quality), yang dapat menciptakan suatu titik pertemuan antara besarnya kepuasan yang diterimapelanggan (pasien) dengan besarnya uang yang dibayarkan oleh pelanggan (pasien) kepada Rumah sakit". ${ }^{11}$

Berdasarkan latar belakang tersebut, dapat dikatakan bahwa terdapat hubungan antara pasien, dokter dan rumah sakit dimana dalam hal tersebut ketiganya memiliki kewajiban dan hak yang setara, harus memberikan penghormatan atas hak satu sama lain guna meminimalisir pelanggaran. Oleh karenanya dokter yang memiliki kode etik dan mengikuti aturan di rumah sakit juga berkewajiban mematuhi Undang-Undang kesehatan dan Undang-Undang Rumah Sakit. Sehingga penulis merumuskan masalah dalam penelitian ini yaitu bagaimana pertanggungjawaban rumah sakit terhadap dokter yang melakukan malpaktik?

\section{METODE}

Penelitian ini merupakan penelitian normatif, yaitu terutama mengkaji kaidah-kaidah (norma-norma) hukum dalam hukum positif. Penelitian ini adalah penelitian hukum normatif atau penelitian hukum kepustakaan, yaitu penelitian yang dilakukan dengan cara meneliti bahan pustaka atau data sekunder belaka. ${ }^{12}$ Sumber data utama penelitian ini adalah studi literatur, yaitu dengan mengamati, mempelajari, membaca materi hukum dan keputusan serta dokumen yang terkait dengan penelitian ini. Literatur tersebut berasal dari kode etik hakimdan UU kehakiman.

\section{HASIL DAN PEMBAHASAN}

\section{Pertanggungjawaban Hukum Rumah Sakit}

Menurut Black's Law Dictionary, tanggung jawab (liability) mempunyai tiga arti, yaitu: an obligation one is bound in law or justice to perform; condition of being responsible for a possible or actual loss; and condition which creates a duty to perform an act immediately or in the future. Tanggung jawab memiliki beberapa unsur yang harus dipenuhi, diantaranya yaitu kecakapan, beban kewajiban, dan perbuatan.Badan hukum dikatakan cakap selama tidak ada putusan yang menyatakan bahwa badan hukum tersebut dalam keadaan pailit oleh suatu pengadilan. Unsur kewajiban memiliki makna hal-hal yang harus dilaksanakan dan yang tidak boleh dilaksanakan, sehingga sifatnya merupakan keharusan. Unsur perbuatan memiliki makna segala sesuatu yang dilakukan.

\footnotetext{
${ }^{10}$ Djaelani, H.A., Dimensi Mutu Jasa Pelayanan Kesehatan Rumah Sakit merupakanKepuasan Pelanggan dan Objek Hukum Kesehatan, “Jurnal Hukum Kesehatan”, Vol. 2 No. 3, 2009, hlm. 43-56.

${ }^{11}$ Cahyono, Op. Cit.

${ }^{12}$ Soerjono Soekanto dan Sri Mamudji, Penelitian Hukum Normatif; Suatu Tinjauan Singkat, PT Raja Grafindo Persada, Jakarta, 2003, hlm. 13
} 
Penyelenggaraan manajemen kesehatan di Rumah Sakit, terdapat pengelolaan yang berkaitan dengan tiga hal yang merupakan tanggung jawab rumah sakit secara umum. Tiga hal tersebut yaitu: pengelolaan rumah sakit yang berkaitan dengan personalia; pengelolaan rumah sakit yang berkaitan dengan pelaksanaan tugas; dan pengelolaan yang berkaitan dengan duty of care. ${ }^{13}$ Oleh karena itu, penyelenggaraan kegiatan rumah sakit terdapat kegiatankegiatan yang menimbulkan tanggung jawab pengelolaan atau manajemen Rumah Sakit dan tanggung jawab para tenaga professional kesehatan di rumah sakit, ${ }^{14}$ yang terdiri dari: tanggung jawab pengelola rumah sakit; dan tanggung jawab tenaga kesehatan (dokter, perawat).Dengan adanya tanggung jawab ini, maka akan memunculkan pula yang namanya kewajiban dari penyelenggara kesehatan. Kewajiban dari rumah sakit yaitu hal-hal yang harus diperbuat atau sesuatu hal yang harus dilaksanakan. Kewajiban dari rumah sakit terbagi dua, yaitu kewajiban sempurna dan kewajiban tidak sempurna. Kewajiban sempurna yaitu kewajiban yang selalu dikaitkan dengan hak orang lain, sedangkan kewajiban tidak sempurna adalah kewajiban yang tidak terkait dengan hak orang lain. ${ }^{15}$ Perbedaan dari kewajiban ini yaitu kewajiban sempurna pada dasarnya merupakan sebuah kewajiban yang harus dilakukan, berbeda dengan kewajiban tidak sempurna yang pada dasarnya merupakan moral untuk bertindak. Dari aspek hukum, kewajiban adalah bentuk beban yang diberikan atau ditentukan oleh hukum kepada orang atau badan hukum. ${ }^{16}$

Rumah sakit yang digolongkan sebagai Badan Hukum maka sudah dapat dimintai pertanggungjawaban dalam segala tindakan hukum yang ia lakukan layaknya manusia. Berdasarkan UU Rumah Sakit, Rumah Sakit bertanggung jawab terhadap semua kerugian yang menimpa seseorang sebagai akibat dari kelalaian tenaga kesehatan di rumah sakit. Pasal 46 UU Rumah Sakit menjadi dasar yuridis untuk seseorang dalam meminta pertanggungjawaban dari pihak rumah sakit jika terjadi kelalaian tenaga kesehatan yang menimbulkan kerugian. Pertanggungjawaban Rumah Sakit dibedakan menjadi pertanggungjawaban kepada pasien selaku pihak pengguna jasa dari badan hukum dan pertanggungjawaban terhadap dokter selaku pekerja di sebuah badan hukum (Rumah Sakit).

\section{Pertanggungjawaban Rumah Sakit Terhadap Dokter}

Sejak diberlakukannya UU Rumah Sakit pada tanggal 28 Oktober 2009 secara yuridis Indonesia sudah memiliki Undang-undang khusus yang mengatur rumah sakit. Pengaturan tersebut sekaligus menjadi dasar hukumbagi rumah sakit dalam melakukan pertanggungjawaban pidana atas tindakan yangdilakukan oleh tenaga kesehatan yang dipekerjakannya. ${ }^{17}$ Pasal 46 UU Rumah Sakit dengan tegas mengatur "Rumah sakitbertanggungjawab secara hukum terhadap semua kerugian yang ditimbulkan ataskelalaian yang dilakukan oleh tenaga kesehatan di rumah sakit." Rumah sakit sebagaiinstusi yang menampung tenaga-tenaga kesehatan tidak dapat lagi lepas daritanggungjawab atas kerugian yang timbul akibat kelalaian yang dilakukan tenagakesehatan dalam melakukan tugas pelayanannya. Semua kerugian yang ditimbulkantenaga kesehatan selama dalam lingkup hubungan kerja menjadi tanggungan penuhrumah sakit. ${ }^{18}$

Rumah Sakit selaku badan hukum membutuhkan orang-orang untuk menjadi pekerjanya. Pekerja di rumah sakit salah satunya adalah dokter. Pertanggungjawaban rumah sakit terhadap dokter pada umumnya tak lepas dari kesalahan yang dilakukan dokter. Kesalahan yang dilakukan dokter dapat disebut dengan malpraktik. Dalam hal ini dapat berupa perbuatan yang disengaja (intentional) seperti pada misconduct tertentu, tindakan kelalaian (negligence), ataupun suatu kekurang mahiran/ketidak kompetenan yang tidak beralasan (unreasonable lack of skill), yang mengakibatkan luka, atau menderita kerugianpada pihak yang ditangani. ${ }^{19}$ Menurut teori atau doktrin, ${ }^{20}$ intensional professional misconduct yaitu dinyatakan bersalah/buruk berpraktik jika dokter dalam berpraktik melakukan pelanggaran terhadap standar-standar dan dilakukan dengan sengaja.Negligence atau tidak sengaja/kelalaian, yaitu seorang dokter yang karena kelalaiannya (culpa) yang mana berakibat cacat atau meninggalnya pasien. Seorang dokter lalai melakukan sesuatu yang seharusnya dilakukan sesuai dengan keilmuan kedokteran. Lack of skill, yaitu dokter melakukan tindakan medis tetapi di luar kompetensinya atau kurang kompetensinya.

\footnotetext{
${ }^{13}$ Husein Kerlaba, Segi-Segi Etis dan Yuridis Informed Concent, (Jakarta: Pustaka Sinar Harapan, 1993$)$, hlm. 97.

${ }^{14}$ Nusye Kl Jayanti,Loc. Cit., hlm. 24.

${ }^{15}$ Setya Wahyudi, Loc. Cit, hlm. 16.

${ }^{16}$ Marwan dan Jimmy, Kamus Hukum: Dictionary of Law, Complete Edition, (Surabaya: Reality Publisher, 2009).

${ }^{17}$ Hwian Christianto, Pertanggungjawaban Pidana Rumah Sakit atas Tindakan Tenaga Kesehatanmenurut UU No. 44 Tahun 2009,“Jurnal Hukum”, 2010, hlm. 6.

${ }^{18}$ Ibid.

${ }^{19}$ Lingkup malpraktik di bidang medik ini, beranjak dari pengertian malpraktik secara umum. Black Law Dictionary,
} seventh edition, Copy Right by West Group Co. 50, West Kellog Boulevard Po. Box 64526 St. Paul Minn, 55164-526, 1999, hlm. 111.

${ }^{20}$ Sudjito bin Atmoredjo, "kajian yuridis malpraktik (tanggung jawab Dokter, Rumah Sakit, dan Hak-Hak Pasien)", makalah disampaikan dalam seminar "penegakan hukum kasus malpraktik serta perlindungan hukum bagi tenaga kesehatan dan pasien", sabtu 18 juli 2009, Unsoed, Purwokerto. 
Jika ditinjau dari perspektif hukum maka malpraktik yang dilakukan oleh tenaga kesehatan dapat merupakan criminal malpractice Civil malpractice medic dan administrative malpractice, ${ }^{21}$ Suatu tindakan medis dapat dikatakan sebagai criminal malpractice jika memenuhi rumusan delik (tindak pidana). Syarat-syarat criminal malpractice yaitu:

1. Merupakan perbuatan tercela (actus reus), baik positive act ataupun negative act.

2. Sikap batin yang salah (mens rea), yaitu berupa kesengajaan (intensional), kecerobohan (recklessness), atau kealpaan (negligence).

Criminal malpractice merupakan tindakan yang melanggar hukum pidana, sehingga saat ini tenaga kesehatan yang melakukan Criminal Malpractice Medic, sama dengan melakukan tindak pidana. ${ }^{22}$ Contoh dari criminal malpractice yang sifatnya sengaja yaitu melakukan aborsi, melakukan euthanasia, membocorkan rahasia kedokteran, tidak melakukan pertolongan terhadap seseorang yang sedang dalam keadaan emergensi meskipun tahu bahwa tidak ada dokter lain yang menolongnya (negative act), menerbitkan surat keterangan dokter yang tidak benar, membuat visum et repertum yang tidak benar. Malpractice medic dalam bentuk kealpaan yaitu kecerobohan berupa kelalaian yang menyebabkan luka berat atau kelalaian pada saat menjalankan jabatan.

Civil malpractice medic yaitu jika seorang tenaga kesehatan tidak melaksanakan kewajiban (ingkar janji, yaitu tidak memberikan prestasinya sebagaimana telah disepakati. Ukuran adanya civil malpractice yaitu (malpraktik perdata), yaitu: adanya kelalaian medik; tindakan medik tanpa persetujuan (perbuatan melanggar hukum); tindakan tanpa consent; pelanggaran janji (wanprestasi). ${ }^{23}$ Tindakan dokter yang termasuk dikategorikan civil malpractice antara lain: tidak melakukan (negative act) apa yang menurut kesepakatan wajib dilakukan; melakukan (positive act) apa yang menurut kesepakatannya wajib dilakukan tetapi terlambat; melakukan sesuatu yang menurut kesepakatan wajib dilakukan tetapi tidak sempurna, dan melakukan apa yang menurut kesepakatannya tidak seharusnya dilakukan. ${ }^{24}$

Kategori administrative malpractice terjadi jika dokter melanggar hukum tata usaha negara. Pemerintah mengeluarkan berbagai macam peraturan di bidang kesehatan dalam rangka melaksanakan police of power. Peraturan tersebut seperti peraturan tentang persyaratan bagi tenaga kesehatan untuk menjalankan profesi medik, batas kewenangan serta kewajibannya. Tenaga kesehatan dapat dipersalahkan jika melanggar peraturan-peraturan tersebut. Contoh tindakan yang digolongkan sebagai tindakan administrative malpractice antara lain: menjalankan praktik kedokteran tanpa izin dari pihak yang berwenang mengeluarkan izin (Dinas Kesehatan), melakukan tindakan medis yang tidak sesuai dengan izin yang dimiliki, melakukan tindakan medis dengan lisensi izin yang sudah kadaluarsa, dan tidak membuat rekam medik.

Ada beberapa macam pola yang berkembang dalam kaitannya dengan hubungan kerja antara tenaga kesehatan (dokter) dan Rumah Sakit, antara lain: dokter sebagai tenaga kerja (employee); dokter sebagai mitra (attending physician); dokter sebagai independent contractor. ${ }^{25}$ Dua pola hubungan yang disebutkan terakhir, lebih menempatkan dokter setara dengan rumahsakit didasarkan atas hubungan kerjasama sehingga pertanggungjawabannya didasarkan atas kesalahan yang ditimbulkan oleh para pihak. Sedangkan dokter sebagaiemployee, dokter berkedudukan sebagai tenaga yang dipekerjakan oleh rumah sakit danrumah sakit sebagai pemberi kerja.

Dokter sebagai salah satu pihak dalam perjanjian memang memiliki prestasi untukmengupayakan penyembuhan pasien melalui pencarian terapi yang paling tepat danbukan pada menjanjikan kesembuhan dari pasien. Oleh karena itu dokter memilikitanggungjawab atas tindakan yang dilakukannya hanya sebatas upaya yang terbaikmenurut ilmu pengetahuan dan pengalaman yang dimilikinya. Obyek perjanjian bukanlahsesuatu hal yang sudah dapat dipastikan tetapi diupayakan dengan cermat dan hati-hati(met zorg en inspanning) sehingga bentuk perjanjian ini merupakan"inspanningverbintenis" bukan "risikoverbintenis". ${ }^{26}$ Kebebasan dokter dalam menentukan diagnosa dan terapi terbaik demi pulihnyakesehatan pasien ini seringkali menemui kendala ketika dikaitkan dengan peraturanRumah sakit. Sebagai pihak pemberi kerja, Rumah sakit menetapkan suatu aturan bagidokter yang bekerja padanya misalnya dalam hal tahapan diagnosa dan terapi (StandarProsedur Operasional) Rumah sakit. Hal yang menarik disini, seorang dokter yangberada dalam ikatan kerja ketika melakukan pelayanan kesehatan memiliki dua hubunganperikatan yang harus dipertimbangkan yaitu sebagai pekerja dengan rumah sakit danpengobat dalam transaksi terapeutik. Kedua hubungan perikatan itu menimbulkanimplikasi bagi kebebasan dokter ketika melakukan

${ }^{21}$ Sofwan Dahlan, Loc. Cit, hlm. 59.

${ }^{22}$ Budi Sampurna, "Malpraktik Medik dan Kelalaian Medik", Universitas Indonesia, Jakarta, Internet, Upload 27 April 2009.

${ }^{23}$ Ibid.

${ }^{24}$ Setya Wahyudi, Loc. Cit, hlm. 12.

25 Sofwan Dahlan, Loc. Cit, hlm. 157

${ }^{26}$ Hermien Hadiati Koeswadji,Hukum Kedokteran: Studi tentang HubunganHukum Dalam Mana Dokter sebagai Salah Satu Pihak, ,Cetakan ke I, (Bandung: Citra Aditya Bakti, 1998), hlm. 110. 
terapi (upaya kesehatan) harusmerujuk pada aturan yang dibuat oleh rumah sakit. Maka dapat dikatakan bahwa para dokter mempunyai kebebasan secaraprofessional, akan tetapi juga dibatasi oleh lingkungan dimana merekabekerja (SOP Rumah Sakit).

Dalam hukum pidana memang tidak dikenal ganti rugi seperti pada hukum perdata, namun pertanggungjawaban tersebut tetap dapat dituntut menggunakan doktrin-doktrin tentang pertanggungjawaban. Rumah sakit sebagai badan hukum (korporasi) dapat dituntut dan dipertanggungjawabkan atas tindakan-tindakan malpraktik tenaga kesehatan di rumah sakit, berdasarkan ajaran-ajaran atau doktrin pembenaran korporasi dibebani pertanggungjawaban sebegai berikut: ${ }^{27}$

1. Doctrine of strict liability

Menurut ajaran ini, pertanggungjawaban dibebankan kepada yang bersangkutan tidak perlu dibuktikan adanya kesalahan (kesengajaan atau kelalaian) pada pelakunya. Ajaran ini disebut pula sebagai absolute liability atau pertanggungjawaban mutlak. Ajaran ini diterapkan terhadap perbuatan-perbuatan yang sangat merugikan kepentingan publik.

2. Doctrine of vicarious liability

Ajaran ini disebut sebagai ajaran pertanggungjawaban pengganti. Seorang majikan bertanggungjawab atas kesalahan-kesalahan yang dilakukan oleh bawahannya sepanjang hal itu terjadi dalam rangka pekerjaannya. Hal ini memberikan kemungkinan kepada pihak yang dirugikan karena perbuatan-perbuatan melawan hukum dari pihak korporasi untuk menggugat majikan korporasi tersebut agar membayar ganti rugi. Dengan ajaran ini, maka korporasi dimungkinkan bertanggungjawab atas perbuatan yang dilakukan oleh pegawainya, kuasanya, mandatarisnya, atau siapa saja yang bertanggungjawab kepada korporasi lewat pimpinan (majikan) dari korporasi tersebut. Penerapan doktrin ini dilakukan setelah dapat dibuktikan terdapat subordinasi antara majikan dan orang yang melakukan tindak kesalahan tersebut, dan perbuatan yang dilakukan dalam lingkup tugas pegawai yang bersangkutan.

3. Doctrine of delegation

Pendelegasian wewenang oleh majikan kepada bawahannya merupakan alasan pembenar bagi dapat dibebankannya pertanggungjawaban kepada majikannya atas perbuatan yang dilakukan oleh bawahannya yang memperoleh pendelegasian wewenang itu.

4. Doctrine of identification

Doktrin ini mengajarkan bahwa untuk dapat mempertanggungjawabkan suatu tindak kesalahan kepada suatu korporasi harus mampu diidentifikasi siapa yang melakukan tindak kesalahan tersebut. Jika tindakan dilakukan personil yang memiliki kewenangan untuk bertindak sebagai directing mind dari korporasi tersebut, maka pertanggungjawaban dibebankan kepada korporasi.

5. Doctrine of aggregation

Doktrin ini mengajarkan bahwa seseorang dianggap mengagregasikan (mengkombinasikan) semua perbuatan dan semua unsur mental/sikap dari berbagai orang yang terkait secara relevan dalam lingkungan perusahaan untuk dapat memastikan bahwa semua perbuatan dan unsur mental tersebut adalah suatu tindak kesalahan seperti seakanakan semua perbuatan dan unsur mental itu telah dilakukan oleh satu orang saja.

Doktrin lainnya yang juga dapat digunakan adalan respondeat superior. Makna dari doktrin ini adalah majikan bertanggung jawab atas tindakan-tindakan pelayan-pelayan yang menjadi tanggung jawabnya, termasuk tindakantindakan yang menimbulkan kerugian bagi orang lain. Doktrin respondeat superior ini menjadi jaminan bahwa ganti rugi diberikan/dibayarkan kepada pasien yang menderita kerugian akibat tindakan medis. selain itu dengan doktrin ini, secara hukum dan keadilan, menghendaki akan sikap kehati-hatian dari para tenaga kesehatan. ${ }^{28}$

Berikut adalah uraian tentang kelalaian tenaga kesehatan di rumah sakit dan pertanggungjawabannya: ${ }^{29}$

1. Jika terdapat dugaan malpraktik oleh tenaga kesehatan di rumah sakit, maka disini terdapat indikasi telah terjadi malpraktik medik dan atau terjadi malpraktik professional di bidang kedokteran.

2. Terjadi malpraktik kedokteran karena tenaga kesehatan tersebut melanggar etika disiplin profesi kedokteran, dan akan diperiksa oleh Majelis Kehormatan Disiplin Kedokteran Indonesia.Majelis Kehormatan Disiplin Kedokteran Indonesia akan menjatuhi sanksi pembinaan kinerja terhadap tenaga kesehatan tersebut.

3. Malpraktik medik yang dilakukan tenaga kesehatan dapat merupakan kealpaan maupun kesengajaan. Jika malpraktik medik ini menimbulkan kerugian, maka pihak rumah sakit akan bertanggung jawab atas kelalaian tenaga kesehatan yang menyebabkan kerugian pada pasien.Rumah sakit akan bertanggung jawab terhadap tindakan kelalaian tenaga kesehatan dengan dasar asas vicarious liability, dan juga sesuai dengan doktrin respondeat

\footnotetext{
${ }^{27}$ Syahrul Machmud, Penegakan Hukum dan Perlindungan Hukum Bagi Dokter yang Diduga Melakukan Medikal Malpraktik, (Bandung: Mandar Maju, 2008), hlm. 229.

${ }^{28}$ Syahrul Machmud, op. cit., hlm. 105.

${ }^{29}$ Setya Wahyudi, op. cit., hlm. 25-27.
} 
superior yang mengandung makna bahwa majikan bertanggung jawab atas tindakan-tindakan pelayan-pelayan yang menjadi tanggung jawabnya.

4. Jika malpraktik medik ini sebagai kesengajaan atau kealpaan, yang merupakan pelanggaran hukum pidana, maka tenaga kesehatan tersebut tetap dapat diajukan ke pengadilan untuk mempertanggungjawabkan atas kelalaian atau kesengajaan tersebut, dan dikenakan sanksi yang berlaku.

Namun jika kerugian yang diakibatkan oleh tenaga kesehatan disebabkan oleh kesengajaan yang ia lakukan maka penuntutan tidak dapat ditujukan kepada rumah sakit. Rumah Sakit tidak akan bertanggung jawab terhadap pasien jika kerugian tersebut terdapat unsur kesengajaan yang dilakukan oleh tenaga kesehatannya.

Oleh sebab itu, implikasi selanjutnya adalah pasien perlu mengetahui bentuk kelalaian tenaga kesehatan yang menjadi tanggung jawab rumah sakit dan bentuk kelalaian tenaga kesehatan yang tidak menjadi tanggung jawab rumah sakit. Sehingga akan ada kondisi dimana tenaga kesehatan akan bertanggung jawab secara langsung terhadap pasien jika kelalaian tersebut dilakukan dengan sengaja. Untuk mendapatkan ganti rugi, pasien harus mengetahui bahwa telah terjadi kelalaian yang dilakukan oleh tenaga kesehatan. Jika pasien tidak mengetahui telah terjadi kelalaian oleh tenaga kesehatan, maka ketentuan yang ada di dalam UU Rumah Sakit tidak dapat direalisasikan.

\section{SIMPULAN}

Tidak setiap kesalahan/kelalaian seorang dokter dalam melaksanakan profesinya dapat dituntut. Hanya yang padanya dapat dibuktikan telah melakukan kelalaian yang berat/kasar (culpa lata) dan jelas kesalahannya yang dapat diajukan ke pengadilan. Apabila tindakan dokter dalam menjalankan profesinya menimbulkan akibat yang tidak dikehendaki, misalnya cacat atau meninggal ataupun akibat lain yang tidak diinginkan, maka dokter tersebut dapat dimintai pertanggungjawaban pidana. Rumah Sakit dalam pelayanan medis menurut UU No. 44 Tahun 2009 tentang Rumah Sakit harus bertanggung jawab penuh terhadap semua kerugian yang ditimbulkan atas kelalaian yang dibuat oleh tenaga medisnya sebagaimana disebutkan dalam Pasal 46. Di samping itu juga tanggung jawab rumah sakit dapat dilihat dari aspek etika profesi, aspek hukum adminitrasi, aspek hukum perdata dan aspek hukum pidana.

\section{DAFTAR PUSTAKA}

Adjie, Oemar Seno.Etika Profesional dan Hukum Pertanggungjawaban PidanaDokter Profesi Dokter. (Jakarta: Erlangga). 1991.

Ameln, Fred.Kapita Selekta Hukum Kedokteran. (Jakarta: PT. Grafika Jaya) 1991.

Aziz, Noor. M. Laporan Penelitian Hukum Tentang Hubungan Tenaga Medik, Rumah Sakit dan Pasien. (Jakarta: Badan Pembinaan Hukum Nasional, Kementerian Hukum dan HAM RI). 2010.

Cahyono,Akhmad Budi dan Sjarif,Surini Ahlan.Mengenal Hukum Perdata. Ed. I.Cet. I, (Jakarta: CV. Gitama Jaya). 2008.

Christianto, Hwian. Pertanggungjawaban Pidana Rumah Sakit atas TindakanTenaga Kesehatanmenurut UU No. 44 Tahun 2009. "Jurnal Hukum". 2010.

Dahlan, Sofwan.Hukum Kesehatan Rambu-Rambu bagi Profesi Dokter.(Semarang: Badan Penerbit Universitas Diponegoro). 2003.

Depdikbud. Kamus Besar Bahasa Indonesia, edisi kedua.(Jakarta: Balai Pustaka). 1995.

Djaelani, H.A. Dimensi Mutu Jasa Pelayanan Kesehatan Rumah Sakit merupakanPelanggan dan Objek Hukum Kesehatan. "Jurnal HukumKesehatan".Vol. 2 No. 3. 2009.

Hatta, Moh.Hukum Kesehatan dan Sengketa Medik, Cet.I. (Yogyakarta: Liberty). 2013.

Indonesia.Undang-undang Tentang Rumah Sakit. UU No. 44 Tahun 2009. LN No. 153 Tahun 2009. TLN No. 5072.

Jacobalis, Samsi.Rumah Sakit: Benturan antara Etika Medis dan Komersialisasi Jasa dalam Rumah Sakit antara Komersialisasi dan Etika. (Jakarta: Gramedia Widiasarana Indonesia). 1995.

Kerlaba, Husein.Segi-Segi Etis dan Yuridis Informed Concent. (Jakarta: PustakaSinar Harapan). 1993.

KI, Nusye Jayanti.Penyelesaian Hukum dalam Malapraktik Kedokteran, Cet. I. (Yogyakarta: Pustaka Yustisia). 2009.

Koeswadji,Hermien Hadiati.Hukum Kedokteran. (Bandung: PT. Citra AdityaBakti).1998.

Koeswadji,Hermien Hadiati.Hukum Kedokteran: Studi tentang HubunganHukum Dalam Mana Dokter sebagai Salah Satu Pihak.Cetakan ke I. (Bandung: Citra Aditya Bakti). 1998.

Koeswadji, Hermein Hadiati.Hukum Untuk Perumahsakitan, (Bandung: Citra Aditya Bakti). 2002.

Machmud, Syahrul.Penegakan Hukum dan Perlindungan Hukum Bagi Dokter yangDiduga Melakukan Medikal Malpraktik. (Bandung: Mandar Maju). 2008.

Marwan dan Jimmy.Kamus Hukum: Dictionary of Law. Complete Edition.(Surabaya: Reality Publisher). 2009.

Notoatmodjo,Soekidjo, Etika \& Hukum Kesehatan.(Jakarta: Rineka Cipta). 2010. 
Praptaningsih,Sri.Kedudukan Hukum Perawat dalam Upaya Pelayanan Kesehatan di Rumah Sakit. (Jakarta: PT. RajaGrafindo Pustaka). 2006.

Seran, et al. Dilema Etika dan Hukum dalam Pelayanan Medis. (Bandung: Mandar Maju). 2010.

Soekanto, Soerjono.Aspek Hukum Kesehatan: Suatu Kumpulan Karangan,Cetakan I. (Jakarta: IND-HILL-Co). 1989.

Soekanto, Soerjono dan Herkutanto.Pengantar Hukum Kesehatan. (Bandung: Remadja Karya). 1987.

Ta’adi.Hukum Kesehatan: Sanksi dan Motivasi Bagi Perawat, ed.2. (Jakarta: EGC). 2011.

Wahyudi, Setya. Tanggung Jawab Rumah Sakit Terhadap Kerugian AkibatKelalaian Tenaga Kesehatan dan Implikasinya, "Jurnal Dinamika Hukum”.Vol. 11, No. 3 September 2011.

Yustina, Endang Wahyati. Mengenal Hukum Rumah Sakit.(Bandung: Keni Media). 2012. 